Check for updates

Cite this: RSC Adv., 2017, 7, 41033

Received 19th May 2017

Accepted 9th August 2017

DOI: $10.1039 / c 7 r a 05670 b$

rsc.li/rsc-advances

\section{Changes in the heavy metal distributions in whole soil and aggregates affected by the application of alkaline materials and phytoremediation}

\author{
Lei Xu, (D) abc Hongbiao Cui, ${ }^{d}$ Xuebo Zheng, (D) e Jun Zhou, ${ }^{\text {abc }}$ Wenhui Zhang, ${ }^{\text {abc }}$ \\ Jiani Liang ${ }^{\text {ab }}$ and Jing Zhou ${ }^{\text {*abcf }}$
}

To explore the combined remedy effect of alkaline materials and plants on the distribution of heavy metals in whole soil and aggregates, a 3 year in situ experiment was carried out in a dual copper (Cu)/cadmium (Cd)-contaminated farmland in this study. Treatment was applied by the addition of soda residue $\left(11.2 \mathrm{t} \mathrm{ha}^{-1}\right)$, apatite $\left(22.3 \mathrm{t} \mathrm{ha}^{-1}\right)$, or lime $\left(4.45 \mathrm{t} \mathrm{ha}^{-1}\right)$, respectively, into the heavy metals-contaminated soil as a single application; Elsholtzia splendens was continually planted for 3 years in all the experimental plots. The total metals amounts and distributions of $\mathrm{Cu}$ and $\mathrm{Cd}$ in the whole soil and aggregates were then investigated. Our results showed that (1) although the total concentrations of $\mathrm{Cu}$ and $\mathrm{Cd}$ were slightly increased in the whole soil, their exchangeable concentrations were significantly reduced in both abovementioned treatments; (2) all the abovementioned 3 treatments significantly increased the stability of the dry and wet aggregates when compared with the control treatment; (3) similar to the whole soil, combined remediation groups slightly increased the concentrations of $\mathrm{Cu}$ and $\mathrm{Cd}$ in the aggregates, but decreased their available and exchangeable concentrations observably. Specifically, the highest concentrations of $\mathrm{Cu}$ and $\mathrm{Cd}$ were found in the aggregates sized $<0.053 \mathrm{~mm}$; however, mass loadings of $\mathrm{Cu}$ and $\mathrm{Cd}$ were observed in the $0.053-0.25 \mathrm{~mm}$ and $0.25-2 \mathrm{~mm}$ sized fractions, respectively; moreover, the treatments increased the mass loading of $\mathrm{Cu}$ and $\mathrm{Cd}$ in the aggregates sized $>0.25 \mathrm{~mm}$. In total, the combined remediation adopted in our study dramatically decreased the available concentrations of both $\mathrm{Cu}$ and $\mathrm{Cd}$ in the whole soil and aggregates. The distribution variations of $\mathrm{Cu}$ and $\mathrm{Cd}$ caused by passivator-plant combined remediation in the whole soil might be because more metal ions have been transformed into less mobile fractions, whereas the heavy metal distribution differences in the aggregates might be not only correlated with the size of the soil wet aggregates, but also possibly controlled by the soil organic carbon.

\section{Introduction}

In most countries, heavy metal contaminated soil is a major concern. Owing to human activities, the issue of contaminated soils in agricultural, industrial, and urban areas has become

${ }^{a}$ Key Laboratory of Soil Environment and Pollution Remediation, Institute of Soil Science, Chinese Academy of Science, Nanjing, 210008, China. E-mail: zhoujing@ issas.ac.cn; Tel: $+86-13913387498$

${ }^{b}$ National Engineering and Technology Research Center for Red Soil Improvement, Red Soil Ecological Experiment Station, Chinese Academy of Sciences, Liujiazhan Plantation, Yingtan 335211, China

'University of Chinese Academy of Sciences, Beijing, 100049, China

${ }^{d}$ School of Earth and Environment, Anhui University of Science and Technology, Huainan, 232001, China

eShandong Industrial Engineering Laboratory of Biogas Production \& Utilization, Key Laboratory of Biofuels, Qingdao Institute of Bioenergy and Bioprocess Technology, Chinese Academy of Sciences, Qingdao, 266101, China

fJiangxi Engineering Research Center of Eco-Remediation of Heavy Metal Pollution, Jiangxi Academy of Science, Nanchang, 330096, China increasingly acute in recent decades. ${ }^{1-3}$ To solve this environmental issue, various remediation technologies, such as thermal treatment, flotation, immobilization, and phytoremediation, have been adopted to remediate heavy metalcontaminated soil. ${ }^{4-6}$ Generally, some of these technologies alone or combined have been proven to be effective to reduce the availability of heavy metals in soil. ${ }^{7,8}$ However, some technologies are not suitable for practical application due to limitations, such as being time-consuming and costly, or involvement of intensive labor needs; the use of plant-based and chemical additives combined in situ remediation technology has been proven to be one of the cheapest and most effective methods for remediating soils contaminated with heavy metals. ${ }^{9-12}$

Various soil factors, such as the soil $\mathrm{pH}$, content of organic matter, heavy metal availability, and biological properties, have been used to evaluate the stabilization effect of the various immobilization technologies. ${ }^{13}$ However, the physical properties of the soil have often been ignored in remediation research. 
In fact, soil aggregates and bulk density can also play key roles in the soil components and particle composition ${ }^{\mathbf{1 4}}$ and should thus be taken into consideration. As the basic unit in the soil system, soil aggregates are a product of the interaction of soil and environmental factors. These aggregates have an effect on the adsorption and distribution of plant nutrients and the binding capacity of heavy metals and other organic toxicants in the soil. ${ }^{15,16}$ A growing body of research has shown that the migration and availability of heavy metals mainly depend on the soil particle size. ${ }^{17}$ The concentration of heavy metals gradually decreases with the increase in soil particle size, with also a big difference in the bioavailability among different fractions. ${ }^{18,19}$ Furthermore, soil aggregates comprise a set of soil particles with different sizes combined with each other in an inorganic and organic composition, where the stability of the aggregates has an important influence on the soil quality and on crop growth. ${ }^{20}$ Heavy metal contamination in soil has intensified the situation of arable soil tension in China to the point where soil remediation is needed to meet the demand for soil reuse for grain production. ${ }^{21}$ So it is very important to study the composition and stability of soil aggregates and the distribution of heavy metals in soil aggregates after the in situ remediation of soil.

Therefore, the main aims of this study were: (1) to evaluate the effects of three kinds of cheap chemical materials (soda residue, apatite, and lime) on the availability and distribution of $\mathrm{Cu}$ and $\mathrm{Cd}$ in whole soil, (2) to explore the effects of combined remediation approaches on the distributions of $\mathrm{Cu}$ and $\mathrm{Cd}$ in soil aggregates, and (3) to explore the possible mechanisms contributing to variations in the distribution of $\mathrm{Cu}$ and $\mathrm{Cd}$.

\section{Materials and methods}

\section{Experiment design}

The experimental site is located in Guixi, Jiangxi Province, China. A subtropical monsoon climate dominates this area, with an annual average precipitation of $1808 \mathrm{~mm}$. Owing to farmers using wastewater containing heavy metals discharged by a local copper smelter for irrigation and due to atmospheric metal depositions and waste residue accumulation, more than $130 \mathrm{hm}^{2}$ of surrounding farmland is suffering from issues with heavy metal pollution (mainly $\mathrm{Cu}$ and $\mathrm{Cd}$ ), resulting in Cd levels in rice exceeding the acceptable level. ${ }^{22}$ The concentration of lead $(\mathrm{Pb})$, zinc $(\mathrm{Zn})$, and arsenic (As) were also determined before the start of the field experiment, and it was found that the concentrations of all of these were below the second grade of soil environmental quality standards in China (GB 156181995).

Field experiments were conducted in triplicate, and were designed with the land split in to randomized blocks or plots. Each plot was $6 \mathrm{~m}^{2}(3 \mathrm{~m} \times 2 \mathrm{~m})$ and the plots were separated by plastic plates. The treatments applied were: (1) $0.5 \%$ soda residue (w/w according to the mass of surface $17 \mathrm{~cm}$ soil, $11.1 \mathrm{t}$ $\mathrm{ha}^{-1}$, the same below), (2) $1 \%$ apatite (22.3 $\left.\mathrm{t} \mathrm{ha}^{-1}\right)$, (3) $0.2 \%$ lime (4.45 $\mathrm{t} \mathrm{ha}^{-1}$ ), and (4) the control. The choice of the doses in the experiments was based on our previous experimental results, and the main properties of the materials are listed in Table 1. The soil and the materials were fully mixed with an agricultural harrow, and then irrigated with tap water after the application of the materials (500 t ha ${ }^{-1}$ ) on December 26, 2012. Elsholtzia splendens were planted with a spacing of $30 \mathrm{~cm} \times 30 \mathrm{~cm}(70$ plants per plot) in every plot on April 26 in 2013, 2014, and 2015 , with a compound fertilizer $\left(\mathrm{N}: \mathrm{P}_{2} \mathrm{O}_{5}: \mathrm{K}_{2} \mathrm{O}=15: 15: 15\right)$ first applied before the plants were planted at a spreading of $0.833 \mathrm{t} \mathrm{ha}^{-1}$. During the study period 2012-2015, these materials were only applied at the start in 2012, while the test crop Elsholtzia splendens was harvested at the beginning of December each year.

\section{Soil and amendments}

Field immobilization remediation was performed throughout the 3 years, whereby soil samples were collected from each plot from an area of $20 \mathrm{~cm} \times 20 \mathrm{~cm} \times 17 \mathrm{~cm}$, with three samples taken from each plot and then mixed together to form a mixed sample. These samples were air dried and sieved using a $5 \mathrm{~mm}$ sieve, and the resulting samples were used for the analysis of soil aggregates. Surface soil $(0-17 \mathrm{~cm})$ was collected and passed through a 10-mesh sieve for determination of the basic properties and to assess the $\mathrm{Cu}$ and $\mathrm{Cd}$ concentrations (Table 1).

The $\mathrm{Cu}$ and $\mathrm{Cd}$ concentrations in the soda residue (particle size $0.25 \mathrm{~mm}$, Sinopec group, Lianyungang soda plant, Jiangsu, China) were 0.412 and $0.0304 \mathrm{mg} \mathrm{kg}^{-1}$, respectively; while those in the apatite (particle size $0.25 \mathrm{~mm}$, Nanzhang Lihua mineral powder factory, Hubei, China) were 9.54 and $1.18 \mathrm{mg} \mathrm{kg}^{-1}$, respectively; and those in the lime (particle size $0.25 \mathrm{~mm}$, building materials market, Jiangxi, China) were 1.36 and $0.87 \mathrm{mg} \mathrm{kg}^{-1}$, respectively; the $\mathrm{pH}$ values of the soda residue, apatite, and lime were $10.1,8.40$, and 12.2 , respectively.

\section{Aggregates analysis}

The dry and wet sieving results were used to measure the soil aggregates according to the methods of Zhang ${ }^{23}$ and Elliott. ${ }^{24}$ The dry aggregates were divided into aggregates sized $>5 \mathrm{~mm}$,

Table 1 The physicochemical properties of the tested soil ${ }^{a}$

\begin{tabular}{|c|c|c|c|c|c|c|c|c|c|c|}
\hline $\mathrm{pH}$ & $\begin{array}{l}\text { SOC } \\
\left(\mathrm{g} \mathrm{kg}^{-1}\right)\end{array}$ & $\begin{array}{l}\text { Total N } \\
\left(\mathrm{g} \mathrm{kg}^{-1}\right)\end{array}$ & $\begin{array}{l}\text { Total P } \\
\left(\mathrm{g} \mathrm{kg}^{-1}\right)\end{array}$ & $\begin{array}{l}\text { Total K } \\
\left(\mathrm{g} \mathrm{kg}^{-1}\right)\end{array}$ & $\begin{array}{l}\text { Available N } \\
\left(\mathrm{mg} \mathrm{kg}^{-1}\right)\end{array}$ & $\begin{array}{l}\text { Available P } \\
\left(\mathrm{mg} \mathrm{kg}^{-1}\right)\end{array}$ & $\begin{array}{l}\text { Available K } \\
\left(\mathrm{mg} \mathrm{kg}^{-1}\right)\end{array}$ & $\begin{array}{l}\text { CEC } \\
\left(\mathrm{cmol} \mathrm{kg}^{-1}\right)\end{array}$ & $\begin{array}{l}\text { Total } \mathrm{Cu} \\
\left(\mathrm{mg} \mathrm{kg}^{-1}\right)\end{array}$ & $\begin{array}{l}\text { Total Cd } \\
\left(\mathrm{mg} \mathrm{kg}^{-1}\right)\end{array}$ \\
\hline 4.63 & 16.3 & 1.33 & 0.261 & 2.38 & 67.1 & 186 & 54.8 & 8.45 & 517 & 0.410 \\
\hline
\end{tabular}

${ }^{a}$ SOC - soil organic carbon, CEC - cation exchange capacity. 
2-5 mm, 1-2 mm, 0.5-1 mm, 0.25-0.5 mm, and <0.25 mm, while the wet aggregates were divided into aggregates sized $>2 \mathrm{~mm}, 0.25-2 \mathrm{~mm}, 0.053-0.25 \mathrm{~mm}$, and $<0.053 \mathrm{~mm}$. On this basis, the contents of $>0.25 \mathrm{~mm}$ mechanically stable aggregates $\left(\mathrm{DR}_{0.25}\right)$ and $>0.25 \mathrm{~mm}$ water-stable aggregates $\left(\mathrm{WR}_{0.25}\right)$ were calculated. $^{25}$

\section{Chemical analysis}

Soil chemical properties. The soil $\mathrm{pH}$ was measured with a glass electrode at a water : soil ratio of 2.5 : 1 (PHS-2CW-CN, Bante, Shanghai, China). The soil organic carbon (SOC) and total nitrogen were determined according to Walkley's method. ${ }^{26}$ The soil available phosphate $(\mathrm{P})$ and nitrogen $(\mathrm{N})$ contents were measured in accordance with Bingham's method. ${ }^{27}$ The ammonium acetate method was used to measure the soil cation exchange capacity (CEC). ${ }^{28}$ The total $\mathrm{Cu}$ and $\mathrm{Cd}$ contents in the whole soil and aggregates were digested with nitric acid $\left(\mathrm{HNO}_{3}\right)$, hydrofluoric acid ( $\left.\mathrm{HF}\right)$, and perchloric acid $\left(\mathrm{HClO}_{4}\right)(5: 10: 5 \mathrm{~mL})$ on an electric heating plate, then the solution content was determined using a flame or graphite furnace atomic absorption spectrophotometer (Model 240AA, Varian, State of California, America). In order to ensure the accuracy of the analysis results, replicate samples, blanks, and a certified reference material (GBW07401, provided by the Institute of Geophysical and Geochemical Exploration, Langfang, Hebei province, China) were included in all the analyses. The available heavy metals in soils were extracted with $0.01 \mathrm{~mol} \mathrm{~L}^{-1}$ $\mathrm{CaCl}_{2}$ and measured according to Walker's method. ${ }^{29}$

Sequential extraction of $\mathbf{C u}$ and $\mathbf{C d}$. Air-dried whole soil was used for the extraction using the modified Tessier sequential extraction procedure following Cui's method, ${ }^{7}$ where the heavy metals were divided into five operationally defined fractions in the following steps:

(1) Exchangeable fraction. $16 \mathrm{~mL}$ of $1 \mathrm{~mol} \mathrm{~L}^{-1} \mathrm{MgCl}_{2}(\mathrm{pH} 7.0)$ was added to a $50 \mathrm{~mL}$ centrifuge tube containing $2 \pm 0.0001 \mathrm{~g}$ of soil. The extraction experiment was carried out under stirring at $120 \mathrm{rpm}$ for $2 \mathrm{~h}$ at $25 \pm 1{ }^{\circ} \mathrm{C}$, then the suspension was centrifuged for $10 \mathrm{~min}$ at $4000 \mathrm{rpm}$, and finally the supernatant was filtered with a $0.45 \mu \mathrm{m}$ membrane and transferred into a $15 \mathrm{~mL}$ centrifuge tube and stored in refrigerator at $4{ }^{\circ} \mathrm{C}$.

(2) Carbonate-bound fraction. $16 \mathrm{~mL}$ of $1 \mathrm{~mol} \mathrm{~L}^{-1} \mathrm{CH}_{3} \mathrm{COONa}$ (adjusted to $\mathrm{pH} 5.0$ with $\mathrm{CH}_{3} \mathrm{COOH}$ ) was added to the residue soil from (1) and shaken in a reciprocating oscillating machine for $3 \mathrm{~h}$ at $25 \pm 1{ }^{\circ} \mathrm{C}$.

(3) $\mathrm{Fe}-\mathrm{Mn}$ oxides-bound fraction. The residue from (2) was shaken with $40 \mathrm{~mL}$ of $0.04 \mathrm{~mol} \mathrm{~L}^{-1} \mathrm{NH}_{2} \mathrm{OH} \mathrm{HCl}$ in $25 \%(\mathrm{v} / \mathrm{v})$ $\mathrm{CH}_{3} \mathrm{COOH}$, followed with occasional agitation for $6 \mathrm{~h}$ at $96 \pm$ $3{ }^{\circ} \mathrm{C}$.

(4) Organic matter-bound fraction. $6 \mathrm{~mL}$ of $0.02 \mathrm{~mol} \mathrm{~L}^{-1} \mathrm{HNO}_{3}$ and $10 \mathrm{~mL}$ of $30 \% \mathrm{H}_{2} \mathrm{O}_{2}$ (adjusted to $\mathrm{pH} 2.0$ with $\mathrm{HNO}_{3}$ ) were added to the residue from (3), and the mixture was heated at 85 $\pm 3{ }^{\circ} \mathrm{C}$ for $2 \mathrm{~h}$ in a water bath. Then, $6 \mathrm{~mL}$ of $30 \% \mathrm{H}_{2} \mathrm{O}_{2}$ (adjusted to $\mathrm{pH} 2.0$ with $\mathrm{HNO}_{3}$ ) was added to the mixture, and the mixture was heated again at $85 \pm 3{ }^{\circ} \mathrm{C}$ for $3 \mathrm{~h}$. After cooling, $10 \mathrm{~mL}$ of $3.2 \mathrm{~mol} \mathrm{~L}^{-1} \mathrm{CH}_{3} \mathrm{COONH}_{4}$ in $20 \%(\mathrm{v} / \mathrm{v}) \mathrm{HNO}_{3}$ was added and the mixture was continuously agitated for $30 \mathrm{~min}$ at $25 \pm 1{ }^{\circ} \mathrm{C}$.
(5) Residual fraction. The residue from (4) was digested with nitric acid $\left(\mathrm{HNO}_{3}\right)$, hydrofluoric acid (HF), and perchloric acid $\left(\mathrm{HClO}_{4}\right)(5: 10: 5 \mathrm{~mL})$ on an electric heating plate.

\section{Statistical analysis}

All the treatments were carried out in triplicate. The means and standard deviations of each treatment were calculated and are presented herein. Differences between the means of the treatments were estimated using one-way ANOVA at a significance level of 0.05 using SPSS 20.0 (IBM SPSS, Somers, NY, USA) when necessary. All the graphics were using Sigmaplot 12.5.

\section{Results and discussion}

\section{Soil characteristics}

After the application of the soil amendments and with the continuous growth of Elsholtzia splendens, the soil $\mathrm{pH}$ became significantly elevated, while the available $\mathrm{Cu}$ and $\mathrm{Cd}\left(\mathrm{CaCl}_{2}-\mathrm{Cu}\right.$ and -Cd) concentrations were significantly decreased (Table 2). Considering the vital role of the soil $\mathrm{pH}$ in controlling the soil solubility, mobility, and bioavailability of heavy metals, ${ }^{30-32}$ the above co-remediation with chemical additives and plants might, through strengthening the soil $\mathrm{pH}$, lead to a lowering of the heavy metal availability. After three years remediation over the whole study period, the SOC contents were significantly increased by the application of these three amendments, respectively. The highest SOC content was observed in the soda residue treatment group, followed by apatite and lime treatment. Also, the SOC concentrations of the different experimental treatments were closely correlated with their corresponding plant biomass (Table 3). The growth of plants might, through increasing the amount of litter and fine roots and through changing the structure of soil aggregates, further lead to an increase in the SOC content. ${ }^{33-35}$ This means that the plant growth could effectively increase the nutrient supply for microbial activities. No significant changes in the total $\mathrm{N}$ and $\mathrm{K}$ were observed between different treatments, but the application of apatite could significantly improve the concentration of the total phosphorus in the soil. This might mainly be due to the application of apatite, which adds a large amount of phosphorus to the soil. Also, given that the test area was in a typical acid rain area, ${ }^{36}$ acid rain may have facilitated the dissolution of apatite. ${ }^{37,38}$ Thus the available phosphorus content in the soil could be improved, which would ultimately lead to promoting phosphorus absorption in plants.

In addition, the total $\mathrm{Cu}$ and $\mathrm{Cd}$ concentrations were slightly increased in the combined repaired soils (Table 2). These results appeared to deviate from the remediation objective of soil remediation, which is to remove heavy metals. Previous studies mostly reported that the total heavy metals concentration showed no significant differences or only a slight decrease relative to that of the control. ${ }^{39}$ This was mainly because of the severe atmospheric deposition in this area, whereby heavy metals could continually enter the soil, ${ }^{40}$ while the surface runoff and leaching amount varied greatly among the different treatments. This could lead to an increased adsorption and 
retention capacity of $\mathrm{Cu}$ and $\mathrm{Cd}$, and a strengthened immobilization efficiency of $\mathrm{Cu}$ and $\mathrm{Cd}$ as well in the treated soil as compared with those in untreated soil. ${ }^{41,42}$

\section{Chemical fractions of $\mathrm{Cd}$ and $\mathrm{Cu}$}

The soil heavy metal forms can be classified into solid and solution phases, where heavy metals are generally more abundant in the solid phase. ${ }^{43}$ Solid-phase heavy metals can be further divided into different fractions, whose solubility, mobility, bioavailability, and potential environmental toxicity cannot be fully reflected by any single-step extraction method. ${ }^{44}$ In the present study, a sequential extraction procedure was used to solve the problem. The different fractions of $\mathrm{Cu}$ and $\mathrm{Cd}$ in the soil were listed in Tables 4 and 5, respectively. The percentage distributions of the $\mathrm{Cu}$ and $\mathrm{Cd}$ fractions in the soil are shown in Fig. 1a and b, respectively.

Without any treatment (i.e., the control group), the RES fraction of $\mathrm{Cu}\left(111 \mathrm{mg} \mathrm{kg}{ }^{-1}, 28.4 \%\right)$ was the most abundant, followed by the OM-fraction (100 $\left.\mathrm{mg} \mathrm{kg}^{-1}, 25.4 \%\right)$, the $\mathrm{Fe}-\mathrm{Mn}$ fraction $\left(74.2 \mathrm{mg} \mathrm{kg}^{-1}, 18.8 \%\right)$, the EXC fraction $\left(71.4 \mathrm{mg} \mathrm{kg}^{-1}\right.$, $18.1 \%$ ), and the CA fraction (36.2 $\left.\mathrm{mg} \mathrm{kg}^{-1}, 9.18 \%\right)$. With the amendments application (soda residue, apatite, or lime), the exchangeable fractions were significantly reduced to $56.3 \mathrm{mg} \mathrm{kg}^{-1}(12.1 \%), 25.2 \mathrm{mg} \mathrm{kg}^{-1}(5.50 \%)$, and $41.2 \mathrm{mg} \mathrm{kg}^{-1}$ $(8.99 \%)$ in turn; while the CA fractions were increased to $59.2 \mathrm{mg} \mathrm{kg}^{-1}$ (12.8\%), $81.9 \mathrm{mg} \mathrm{kg}^{-1}(17.5 \%)$, and $68.7 \mathrm{mg} \mathrm{kg}^{-1}$ (15.1\%), respectively; the RES-fractions were increased to $137 \mathrm{mg} \mathrm{kg}^{-1}$ (29.8\%), $127 \mathrm{mg} \mathrm{kg}^{-1}$ (28.0\%), and $162 \mathrm{mg} \mathrm{kg}^{-1}$ $(35.8 \%)$, respectively. No significant differences in the other factions were obtained as compared with the control.

In the untreated soil, the main form of $\mathrm{Cd}$ was the RES fraction $\left(162 \mu \mathrm{g} \mathrm{kg}^{-1}, 40.1 \%\right)$, similar to the distribution of $\mathrm{Cu}$. Additionally, the exchangeable fraction $\left(158 \mu \mathrm{g} \mathrm{kg}{ }^{-1}, 39.2 \%\right)$ was markedly greater than the CA fraction $\left(14.9 \mu \mathrm{g} \mathrm{kg}^{-1}, 3.69 \%\right)$. With the amendments application (soda residue, apatite, or lime), the exchangeable fractions of $\mathrm{Cd}$ were significantly reduced to $91.8 \mu \mathrm{g} \mathrm{kg}^{-1}$ (23.2\%), $86.0 \mu \mathrm{g} \mathrm{kg} \mathrm{kg}^{-1}$ (21.2\%), and $108 \mu \mathrm{g} \mathrm{kg}^{-1}(25.2 \%)$, respectively, while the RES and Fe-Mn fractions were markedly increased to 224 and $40.7 \mu \mathrm{g} \mathrm{kg}^{-1}$ (56.6\%, 10.3\%), 239 and $47.1 \mu \mathrm{g} \mathrm{kg}^{-1}(59.1 \%, 11.3 \%)$, and 144 and $55.7 \mu \mathrm{g} \mathrm{kg}^{-1}(33.6 \%, 19.1 \%)$, respectively. No significant differences in the other two factions were observed when compared with the control.

The exchangeable fraction of heavy metals is considered the most easily mobile and available ${ }^{45}$ form. Additionally, the carbonate-, Fe-Mn oxides-, and organic matter-bound fractions of heavy metals are potentially available to plants and microorganisms, while the residual fraction was dominant among the five fractions. The exchangeable and CA-bound fractions of $\mathrm{Cu}$ are often present in uncontaminated soil at low concentrations $(<10 \%$ of total $\mathrm{Cu}) .{ }^{46} \mathrm{In}$ the present study, the exchangeable and carbonate-bound fractions of $\mathrm{Cu}$ constituted $27.3 \%$ of the total $\mathrm{Cu}$ in the untreated soil, which made it inappropriate for agricultural use. We conjectured that the source of $\mathrm{Cu}$ was mainly artificial and introduced from exhaust gases, dust, and wastewater from the nearby copper smelter. 
Table 3 Shoot biomass of Elsholtzia splendens from each treatment over the 3 year study period ${ }^{a}$

Shoot biomass (kg dry weight per plot per year)

\begin{tabular}{lllll}
\cline { 2 - 4 } Treatment & 2013 & 2014 & 2015 & Total shoot biomass \\
\hline Control & - & - & - & - \\
Soda residue & $7.29 \pm 0.904 \mathrm{ab}$ & $9.53 \pm 0.822 \mathrm{a}$ & $7.31 \pm 0.945 \mathrm{a}$ & $24.1 \pm 0.265 \mathrm{a}$ \\
Apatite & $4.90 \pm 1.04 \mathrm{~b}$ & $8.24 \pm 1.39 \mathrm{a}$ & $7.20 \pm 0.291 \mathrm{a}$ & $21.2 \pm 1.34 \mathrm{~b}$ \\
Lime & $7.79 \pm 1.58 \mathrm{a}$ & $7.10 \pm 1.04 \mathrm{a}$ & $6.28 \pm 1.41 \mathrm{a}$ & $20.3 \pm 1.15 \mathrm{~b}$
\end{tabular}

${ }^{a}$ The different lowercase letters indicate significant differences between treatments in the same year $(n=3, P<0.05)$; - indicates no plant growth.

Table 4 Effects of soda residue, apatite, and lime application on $\mathrm{Cu}$ fractions. EXC $=$ exchangeable fraction, $C A=$ carbonate-bound fraction, $\mathrm{Fe}-\mathrm{Mn}=\mathrm{Fe}-\mathrm{Mn}$ oxides-bound fraction, $\mathrm{OM}=$ organic matter-bound fraction, RES = residual fraction. Different lowercase letters indicate significant differences between treatments after three years $(n=3, P<0.05)$

\begin{tabular}{lllcc}
\hline Treatment & EXC, $\mathrm{mg} \mathrm{kg}^{-1}$ & $\mathrm{CA}, \mathrm{mg} \mathrm{kg}$ & $\mathrm{Fe}-\mathrm{Mn}, \mathrm{mg} \mathrm{kg}^{-1}$ & ${\mathrm{OM}, \mathrm{mg} \mathrm{kg}^{-1}}^{\mathrm{RES}_{\mathrm{mg} \mathrm{kg}} \mathrm{mg}^{-1}}$ \\
\hline Control & $71.4 \pm 6.66 \mathrm{a}$ & $36.2 \pm 1.94 \mathrm{~b}$ & $74.2 \pm 5.20 \mathrm{a}$ & $100 \pm 4.88 \mathrm{a}$ \\
Soda residue & $56.3 \pm 11.0 \mathrm{ab}$ & $59.2 \pm 10.8 \mathrm{ab}$ & $121 \pm 28.0 \mathrm{a}$ & $88.8 \pm 9.68 \mathrm{ab}$ \\
Apatite & $25.2 \pm 11.3 \mathrm{c}$ & $81.9 \pm 21.9 \mathrm{a}$ & $133 \pm 39.6 \mathrm{a}$ & $94.7 \pm 15.3 \mathrm{a}$ \\
Lime & $41.2 \pm 12.6 \mathrm{bc}$ & $68.7 \pm 4.77 \mathrm{ab}$ & $113 \pm 2.67 \mathrm{a}$ & $68.92 \mathrm{~b}$ \\
\end{tabular}

Table 5 Effects of soda residue, apatite, and lime application on Cd fractions. EXC $=$ exchangeable fraction, CA $=$ carbonate-bound fraction, $\mathrm{Fe}-\mathrm{Mn}=\mathrm{Fe}-\mathrm{Mn}$ oxides-bound fraction, $\mathrm{OM}=$ organic matter-bound fraction, $\mathrm{RES}=$ residual fraction. Different lowercase letters indicate significant differences between treatments after three years $(n=3, P<0.05)$

\begin{tabular}{lcccr}
\hline Treatment & EXC, $\mu \mathrm{g} \mathrm{kg}^{-1}$ & $\mathrm{CA}, \mu \mathrm{g} \mathrm{kg}{ }^{-1}$ & $\mathrm{Fe}-\mathrm{Mn}, \mu \mathrm{g} \mathrm{kg}{ }^{-1}$ & $\mathrm{OM}, \mu \mathrm{g} \mathrm{kg}^{-1}$ \\
\hline Control & $158 \pm 29.4 \mathrm{a}$ & $14.9 \pm 3.85 \mathrm{a}$ & $30.2 \pm 8.10 \mathrm{~b}$ & $38.8 \pm 15.3 \mathrm{a}$ \\
Soda residue & $91.8 \pm 12.3 \mathrm{~b}$ & $12.7 \pm 2.76 \mathrm{a}$ & $40.7 \pm 4.83 \mathrm{a}$ & $26.5 \pm 7.97 \mathrm{a}$ \\
Apatite & $86.0 \pm 16.8 \mathrm{~b}$ & $17.0 \pm 5.46 \mathrm{a}$ & $47.1 \pm 11.4 \mathrm{a}$ & $224 \pm 11.4 \mathrm{a}$ \\
Lime & $108 \pm 4.82 \mathrm{~b}$ & $14.9 \pm 1.48 \mathrm{a}$ & $55.7 \pm 1.19 \mathrm{a}$ & $37.2 \pm 3.71 \mathrm{a}$
\end{tabular}

Additionally, the exchangeable fraction can be used to evaluate the bioavailability and environmental toxicity of heavy metals. ${ }^{47,48}$ In the current study, the concentrations of $\mathrm{Cu}$ and Cd were decreased in the exchangeable fraction but increased in the Fe-Mn oxides-bound and residual fractions after the amendments application compared with that of the control. This result illustrated that all three kinds of amendments could significantly reduce the bioavailability of $\mathrm{Cu}$ and $\mathrm{Cd}$ in the contaminated soil, and thus were effective in remediating the soils contaminated with the two metals. The exchangeable fraction of $\mathrm{Cd}(39.2 \%)$ was greater than that of $\mathrm{Cu}(18.1 \%)$ in the untreated soil, indicating a higher mobility of Cd than that of $\mathrm{Cu}$ at this contaminated site.

\section{Distribution of the soil aggregate fraction}

As the basic unit of soil structure, soil aggregates are made up of individual soil particles and organic matter, which makes the, one of the most important factors to determine soil fertility. The size and stability of soil aggregates exert direct effects on soil aeration and water availability, and are closely related to the soil's physical, chemical, and biological characteristics and plant growth. ${ }^{49}$ The content of mechanical stability aggregates $\left(\mathrm{DR}_{0.25}\right)$ were $46.7-55.1 \%$ before the plants were harvested in
2015 (Table 6) in this study. This content was lower than that in many other reports, ${ }^{\mathbf{5 0 , 5 1}}$ and highlighted the poor physical structure of the soil in this area. This might be related to the serious soil pollution in this area, which resulted in difficult plant growth and a higher intensity of surface erosion, which both eventually have led to deterioration of the soil structure. The content of the mechanical stability aggregates $\left(\mathrm{DR}_{0.25}\right)$ increased by $2.57-17.9 \%$ after 3 years of combined remediation of three different materials and Elsholtzia splendens (Table 6) over the course of this 3 year study. The combined remediation mainly changed the content in the $2-5 \mathrm{~mm}, 1-2 \mathrm{~mm}$, and $0.25-$ $0.5 \mathrm{~mm}$ sized aggregates by $12.8-29.4 \%, 18.5-29.8 \%$, and $18.5-$ $22.6 \%$ (Table 6), respectively.

For the water-stable aggregates, the content of water-stable aggregates $\left(\mathrm{WR}_{0.25}\right)$ ranged from $49.1 \%$ to $56.8 \%$ (Table 6 ). The combined remediation significantly increased the content of water-stable aggregates by $6.11-15.7 \%$. This indicated that the effect of vegetation restoration on the mechanical stability aggregates was more obvious than on the water-stable aggregates during the in situ remediation. The combined remediation mainly changed the content of aggregates sized $>2 \mathrm{~mm}$ by $29.6-41.3 \%$.

This study clearly showed that the content of mechanical stability aggregates $\mathrm{DR}_{0.25}$ and water-stable aggregates $\mathrm{WR}_{0.25}$ in 

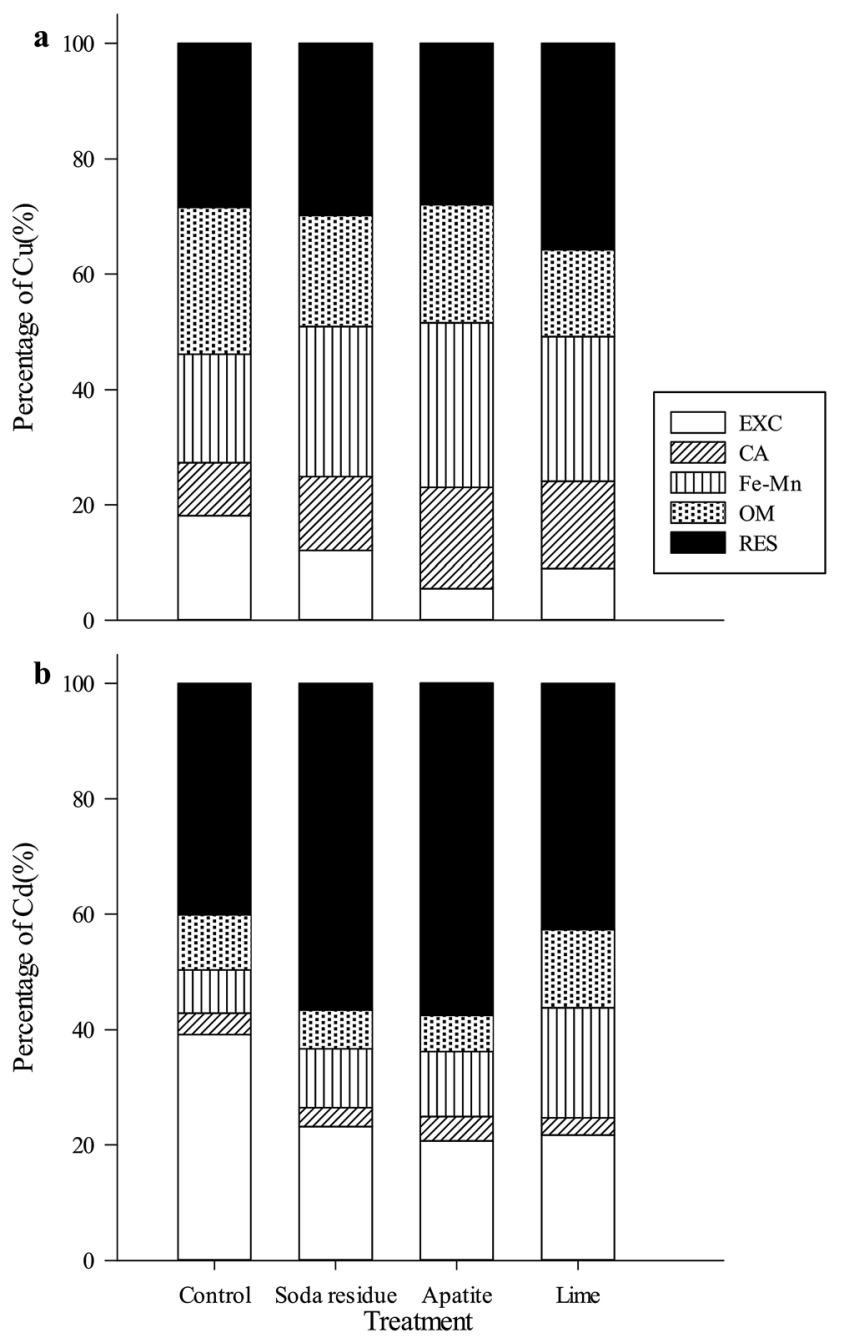

Fig. 1 Effects of soda residue, apatite, and lime application on the percentages of: (a) $\mathrm{Cu}$ and (b) $\mathrm{Cd}$ fractions after three years. EXC = exchangeable fraction, $\mathrm{CA}=$ carbonate-bound fraction, $\mathrm{Fe}-\mathrm{Mn}=\mathrm{Fe}-$ Mn oxides-bound fraction, $O M=$ organic matter-bound fraction, RES $=$ residual fraction. the soil were greatly increased after the remediation, especially the concentration of aggregates sized $>2 \mathrm{~mm}$. These results indicated that the combined remediation measures had positively contributed to the formation of soil stable aggregates in this region, which could further support reestablishing vegetation (Elsholtzia splendens). The stability of the soil aggregates was closely related to the level of organic carbon. Soil organic carbon could promote the cementation of soil particles, whereby inorganic colloids play a dominant role during the formation of agglomerates in bare land because of the absence of organic matter. ${ }^{52}$ Vegetation restoration increased the amount of litter and root exudates, thus benefiting the accumulation of organic carbon (Table 2), especially for new organic carbon, where the new organic carbon in soil could cement smaller aggregates to form stable aggregates, ${ }^{53}$ which consequently improved the content of stability aggregates.

\section{Concentration of SOC in the wet aggregate fractions}

The largest concentration of SOC was found in the aggregate size fraction $0.25-2 \mathrm{~mm}$ and ranged from 18.6 to $23.3 \mathrm{~g} \mathrm{~kg}^{-1}$, followed by those in the fractions sized $>2 \mathrm{~mm}$ $\left(16.4-19.9 \mathrm{~g} \mathrm{~kg}^{-1}\right),<0.053 \mathrm{~mm}\left(10.8-12.8 \mathrm{~g} \mathrm{~kg}^{-1}\right), 0.053-0.25 \mathrm{~mm}$ (9.24-10.9 $\mathrm{g} \mathrm{kg}^{-1}$ ) in turn (Fig. 2). These results confirmed that the concentration of SOC in $>0.25 \mathrm{~mm}$ aggregates was greater than that in smaller aggregates; this result was similar to John, ${ }^{54}$ who found that the SOC content in micro-aggregates was lower than that in macro-aggregates, and the SOC content in $>2 \mathrm{~mm}$ aggregates was 3.62 times higher than that in $<0.053 \mathrm{~mm}$ aggregates in the farmland tested. In addition, the combined remediation significantly increased the concentration of SOC in all the aggregate fractions compared with the control, and in the $>2$ and $0.053-0.25 \mathrm{~mm}$ sized aggregate fractions it followed the order: soda residue $>$ lime $>$ apatite $>$ control (Fig. 2); while in the $0.25-2$ and $<0.053 \mathrm{~mm}$ sized aggregate fractions, it followed the order: apatite $>$ soda residue $>$ lime $>$ control. This might be

Table 6 Composition of aggregates in the soil after the remediation (\%). Mechanical stability aggregates $\left(\mathrm{DR}_{0.25}\right)$ and water-stable aggregates $\left(W_{0.25}\right)$. Different lowercase letters indicate significant differences between treatments after three years $(n=3, P<0.05)$

\begin{tabular}{|c|c|c|c|c|c|c|c|}
\hline \multirow[b]{2}{*}{ Treatment } & \multicolumn{7}{|c|}{ Sizes of the soil mechanical-stable aggregates } \\
\hline & $>5 \mathrm{~mm}$ & $5-2 \mathrm{~mm}$ & $2-1 \mathrm{~mm}$ & $1-0.5 \mathrm{~mm}$ & $0.5-0.25 \mathrm{~mm}$ & $<0.25 \mathrm{~mm}$ & $\mathrm{DR}_{0.25}$ \\
\hline Control & $6.77 \pm 1.59 \mathrm{a}$ & $8.61 \pm 1.86 \mathrm{ab}$ & $4.74 \pm 1.48 b$ & $7.48 \pm 0.589 a$ & $17.4 \pm 1.23 \mathrm{c}$ & $51.4 \pm 3.22 \mathrm{a}$ & $46.7 \pm 2.58 b$ \\
\hline Soda residue & $7.22 \pm 0.29 \mathrm{a}$ & $8.29 \pm 0.418 b$ & $6.21 \pm 0.287 \mathrm{ab}$ & $5.22 \pm 1.13 b$ & $22.9 \pm 1.16 \mathrm{a}$ & $49.7 \pm 1.82 \mathrm{ab}$ & $50.1 \pm 1.86 \mathrm{ab}$ \\
\hline Apatite & $7.39 \pm 0.855 a$ & $9.41 \pm 0.442 \mathrm{ab}$ & $6.20 \pm 0.686 \mathrm{ab}$ & $6.66 \pm 0.843 \mathrm{ab}$ & $17.3 \pm 0.605 c$ & $51.4 \pm 2.25 \mathrm{a}$ & $47.9 \pm 0.447 \mathrm{~b}$ \\
\hline Lime & $7.26 \pm 1.58 \mathrm{a}$ & $11.6 \pm 1.42 \mathrm{a}$ & $7.63 \pm 1.10 \mathrm{a}$ & $7.31 \pm 0.397 \mathrm{a}$ & $20.6 \pm 1.27 \mathrm{~b}$ & $44.0 \pm 3.43 \mathrm{~b}$ & $55.1 \pm 3.29 \mathrm{a}$ \\
\hline
\end{tabular}

Sizes of the soil water-stable aggregates

\begin{tabular}{|c|c|c|c|c|c|}
\hline Treatment & $>2 \mathrm{~mm}$ & $0.25-2 \mathrm{~mm}$ & $0.053-0.25 \mathrm{~mm}$ & $<0.053 \mathrm{~mm}$ & $\mathrm{WR}_{0.25}$ \\
\hline Control & $17.9 \pm 0.489 \mathrm{~b}$ & $31.2 \pm 2.11 \mathrm{a}$ & $45.8 \pm 2.82 \mathrm{a}$ & $3.76 \pm 0.212 \mathrm{a}$ & $49.1 \pm 1.63 \mathrm{~b}$ \\
\hline Soda residue & $25.3 \pm 0.600 \mathrm{a}$ & $31.5 \pm 0.441 \mathrm{a}$ & $38.4 \pm 0.855 b$ & $3.88 \pm 0.211 \mathrm{a}$ & $56.8 \pm 1.04 \mathrm{a}$ \\
\hline Apatite & $23.2 \pm 2.26 a$ & $28.9 \pm 0.700 \mathrm{a}$ & $40.7 \pm 2.26 \mathrm{ab}$ & $4.12 \pm 0.838 a$ & $52.1 \pm 2.96 \mathrm{ab}$ \\
\hline Lime & $24.5 \pm 2.88 \mathrm{a}$ & $30.3 \pm 0.106 \mathrm{a}$ & $38.0 \pm 2.63 b$ & $3.75 \pm 0.522 \mathrm{a}$ & $54.8 \pm 2.98 \mathrm{ab}$ \\
\hline
\end{tabular}




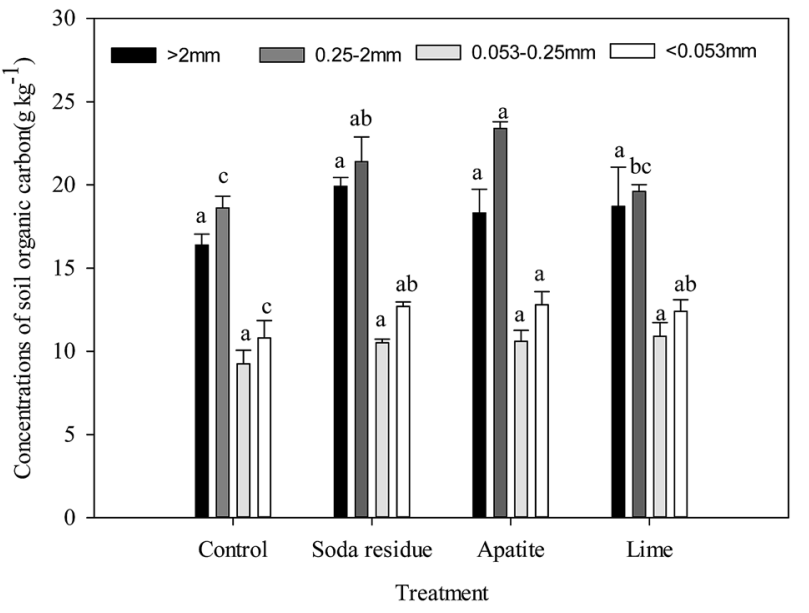

Fig. 2 Concentrations of soil organic carbon $\left(\mathrm{g} \mathrm{kg}^{-1}\right)$ in different size fractions of wet soil aggregates. Different lowercase letters indicate significant differences between treatments after three years $(n=3, P<$ 0.05).

due to the larger Elsholtzia splendens biomass exhibited in the soda residue- and lime-treated soils (Table 3), where the increase of biomass then resulted in an increase in plant litter and rhizosphere exudates in the soil, which further elevated the content of organic carbon in the soil. ${ }^{55}$

\section{Content of $\mathrm{Cu}$ and $\mathrm{Cd}$ in the wet aggregate fractions}

Previous studies have shown that wet aggregates can be used to study changes in the SOC content and microbial community structure as well as the distribution of heavy metals in long-term soil use. ${ }^{\mathbf{1 4 5 6}}$ Moreover, in our study, a subtropical monsoon climate dominates the area, with an annual average precipitation of $1808 \mathrm{~mm}$, therefore, it was necessary to evaluate the water stability of the aggregates. Soil resistance against water erosion can be well demonstrated by $\mathrm{WR}_{0.25} \cdot{ }^{57}$ Thus, this study was mainly focused on examining the content of $\mathrm{Cu}$ and $\mathrm{Cd}$ in the wet soil aggregate fractions.

The highest concentrations of $\mathrm{Cu}$ and $\mathrm{Cd}$ were found in the $<0.053 \mathrm{~mm}$ sized fraction, followed by the $0.25-2,>2$, and $0.053-$
$0.25 \mathrm{~mm}$ sized fractions (Table 7). The concentrations of $\mathrm{Cu}$ and Cd in both the $>2$ and $0.25-2 \mathrm{~mm}$ sized fractions followed the order of soda residue $>$ apatite $>$ lime $>$ control, while the $\mathrm{Cu}$ concentration in both the $0.053-0.25$ and $<0.053 \mathrm{~mm}$ sized fractions followed the descending order of apatite $>$ soda residue $>$ lime $>$ control. The $\mathrm{Cd}$ concentration in the 0.053-0.25 $\mathrm{mm}$ sized fraction followed the order: soda residue $>$ lime $>$ apatite $>$ control, while in the $<0.053 \mathrm{~mm}$ sized fraction, it followed the order lime $>$ apatite $>$ soda residue $>$ control (Table 7). The highest mass loading concentrations of $\mathrm{Cu}$ and $\mathrm{Cd}$ were obtained in the $0.25-2 \mathrm{~mm}$ sized fraction $(39.9-42.5 \%$ and $36.1-$ $39.4 \%$ ), followed by the $0.053-0.25$ (26.7-32.4\% and $32.9-$ $39.2 \%),>2(21.3-27.2 \%$ and $15.2-24.3 \%)$, and $<0.053 \mathrm{~mm}(5.85-$ $6.37 \%$ and $5.56-7.06 \%$ ) sized fractions, respectively (Fig. 3).

Similar to the results of $\mathrm{Xu},{ }^{58}$ the present study found that the highest concentrations of heavy metals were found in the smallest aggregates $(<0.053 \mathrm{~mm})$, which might be due to the larger surface area of the small aggregates. ${ }^{59}$ The silt and clay were the main components in the $<0.053 \mathrm{~mm}$ sized fraction, where metals might act as the binding agents for the claypolyvalent metal-organic matter complexes. ${ }^{60}$ Thus, heavy metals could easily accumulate on their large surfaces by adsorption, forming chelating complexes with the organicmineral colloidal particles in the finest fractions. ${ }^{61}$ Furthermore, the $\mathrm{Cu}$ and $\mathrm{Cd}$ concentrations in all the wet soil aggregate fractions of the treatments were slightly increased, which might be attributed to the higher content of total $\mathrm{Cu}$ and $\mathrm{Cd}$ in the treated whole soil than in the control (Table 2).

In addition, although the concentration of $\mathrm{Cu}$ and $\mathrm{Cd}$ in the $<0.053 \mathrm{~mm}$ sized aggregates was the fundamental part, the mass loading levels were not predominant, which was consistent with the previous findings showing there was only 2.9$18.3 \%$ heavy metals loading in the $<0.045 \mathrm{~mm}$ sized fraction. ${ }^{62}$ Meanwhile, the $>2$ and $0.25-2 \mathrm{~mm}$ sized fractions played important roles as $\mathrm{Cu}$ and $\mathrm{Cd}$ reservoirs in all the soils. Notably, the mass loading capacities of $\mathrm{Cu}$ and $\mathrm{Cd}$ in the $>2$ and 0.25-2 $\mathrm{mm}$ sized aggregates were markedly promoted after adding the amendments. This was due partly to the higher aggregate content of the $>2$ and $0.25-2 \mathrm{~mm}$ sized aggregates. Meanwhile, the content of heavy metals in the atmospheric deposition was

Table 7 Concentrations of total $\mathrm{Cu}$ and $\mathrm{Cd}$ in different size aggregates of wet soil aggregates for different treatments. Different lowercase letters indicate significant differences between treatments after three years $(n=3, P<0.05)$

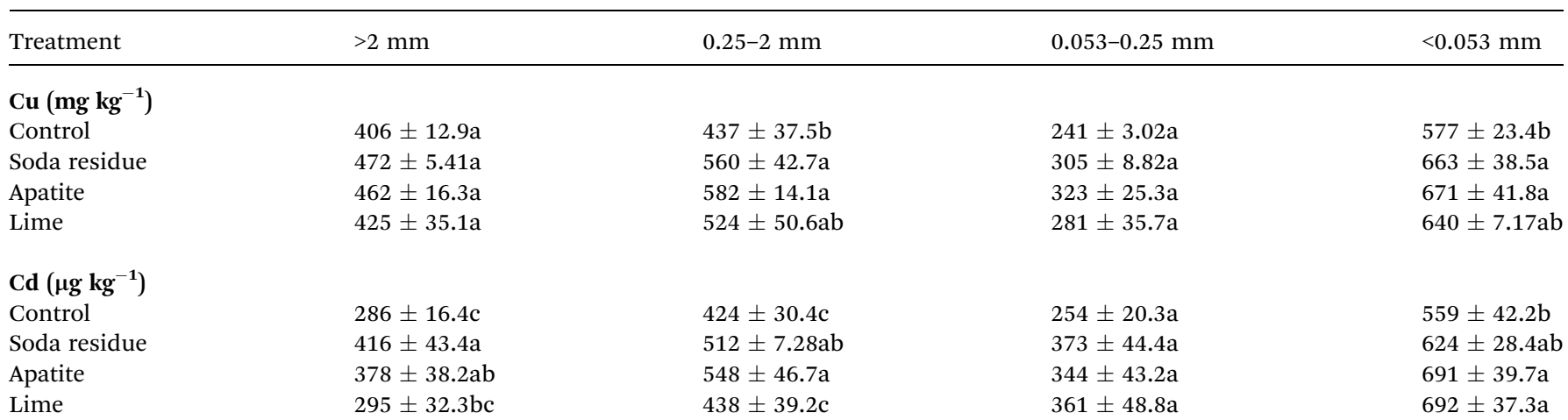




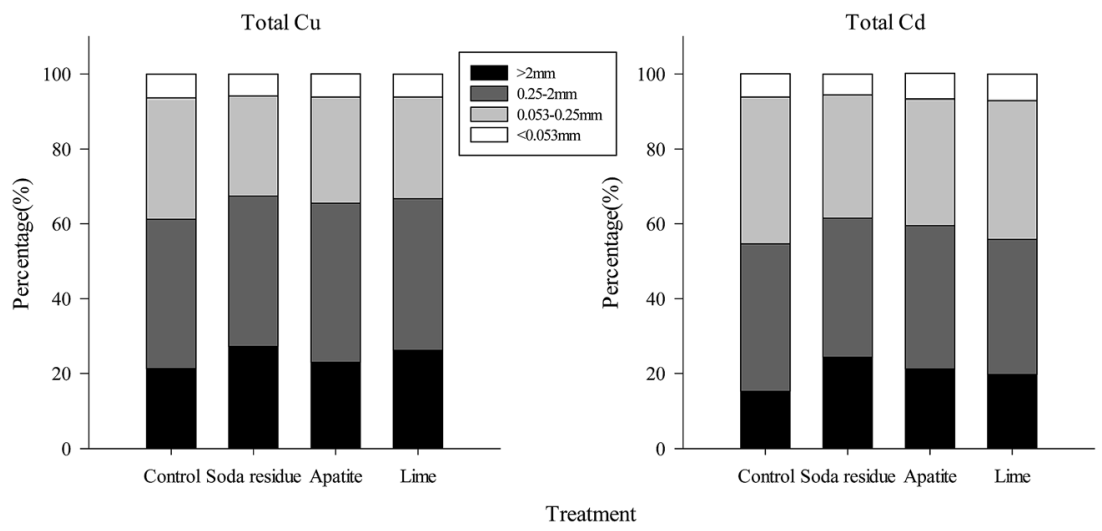

Fig. 3 Total $\mathrm{Cu}$ and $\mathrm{Cd}$ mass loading values of four size fractions $(\mathrm{mm})$.

Table 8 The correlation between the concentration and mass loading of $\mathrm{Cu}$ and $\mathrm{Cd}$ and the concentrations of SOC and soil wet aggregates. Different lowercase letters indicate significant differences between treatments after three years $(n=48, * * * P<0.001, * * P<0.01$ and $* P<0.05)$

\begin{tabular}{llllll}
\hline Factor & & Cu concentration & Cu mass loading & Cd concentration & Cd mass loading \\
\hline SOC & $r$ & $0.376^{* *}$ & $0.558^{* * *}$ & 0.008 & 0.256 \\
& $P$ & 0.009 & $<0.0001$ & 0.956 & 0.078 \\
Size of soil wet aggregates & $r$ & $-0.756^{* * *}$ & $0.718^{* * *}$ & $-0.805^{* * *}$ & $<0.923^{* * *}$ \\
& $P$ & $<0.0001$ & $<0.0001$ & $<0.0001$
\end{tabular}

high in this area, with some of the new input of heavy metals being first adsorbed on the surface of the micro-aggregates, and then the fine soil particles, leading to a high concentration of heavy metals and the formation of macro-aggregates under the action of SOC. ${ }^{63}$ In our combination remediation, the content of organic carbon in soil was raised because of the better growth of plants, which subsequently promoted the transition of soil from the micro-aggregates to macro-aggregates. This eventually led to the transfer of heavy metals from micro-aggregates into macroaggregates. This may be the possible reason for the increased mass loading levels of $\mathrm{Cu}$ and $\mathrm{Cd}$ in the $>0.25 \mathrm{~mm}$ sized aggregates following the chemical-plant treatments.

Moreover, previous studies have shown that SOC could affect the transportation and distribution of heavy metals in the soil through terrestrial ecosystems. In our present study, the concentration and mass loading of $\mathrm{Cu}$ in the wet aggregates were significantly positively correlated with SOC $\left(r_{\text {SOC-Cu concentration }}=0.376^{* *}, r_{\text {SOC-Cu mass loading }}=0.558^{* * *}\right.$, Table 8) which indicated that the SOC might control the distribution of $\mathrm{Cu}$ in the wet aggregates. However, the distribution of $\mathrm{Cd}$ in the aggregates was not significantly correlated with the SOC content. These results also agreed with those of Egli et al. ${ }^{64}$ who found that $\mathrm{Cu}$ and $\mathrm{Pb}$ concentrations were significantly correlated with the labile organic carbon pools, and the content of SOC could affect the storage capacity and mobility of $\mathrm{Cu}$ and $\mathrm{Pb}$ in soils. Furthermore, we found a significant relationship between the size of the soil wet aggregates and both the concentrations and mass loading of $\mathrm{Cu}$ and $\mathrm{Cd}$ (Table 8); these results also agreed with those of Cui et al. ${ }^{\mathbf{4 1}}$ Thus, we speculated that the concentration and distribution of $\mathrm{Cu}$ and $\mathrm{Cd}$ in the wet soil aggregate fractions were not only controlled by the size of the soil wet aggregates, but also by the SOC concentrations.

\section{Conclusion}

This study demonstrates the benefits of combining three kinds of amendments application and Elsholtzia splendens for improving soil quality during the process of heavy metals remediation of contaminated soils. The application of soda residue, apatite, or lime could increase the soil $\mathrm{pH}$ and decrease the available and exchangeable $\mathrm{Cu}$ and $\mathrm{Cd}$ concentrations in a smelter-impacted soil. In addition, after 3 years of the combined remediation, the concentration of SOC in the whole soil and in wet aggregates was dramatically improved, while the $\mathrm{DR}_{0.25}$ and $\mathrm{WR}_{0.25}$ also were significantly improved. The treatments increased the mass loading of $\mathrm{Cu}$ and $\mathrm{Cd}$ in the $>0.25$ $\mathrm{mm}$ sized aggregates, where the distribution of total $\mathrm{Cu}$ and $\mathrm{Cd}$ were not only significantly related to the size of soil wet aggregates, but also correlated with the SOC concentration in wet soil aggregates. Additionally, this study reminded us that the soil's physical indexes, such as soil aggregate stability, should be taken into consideration in the assessment of heavy metal contaminated soil remediation, especially for the purpose of improving the crop yield through remediation.

\section{Conflicts of interest}

There are no conflicts to declare. 


\section{Acknowledgements}

The authors acknowledge the National Basic Research Program of China (2013CB934302), the National Science and Technology Support Plan (2015BAD05B01), and the National Natural Science Foundation of China (41571461, 41601340).

\section{References}

1 Y. Yao, Nature, 2016, 533, 469.

2 A. Mahar, W. Ping, L. Ronghua and Z. Zhang, Pedosphere, 2015, 25, 555-568.

3 R. Xiao, X. Sun, J. Wang, J. Feng, R. Li, Z. Zhang, J. J. Wang and A. Amjad, J. Anal. Appl. Pyrolysis, 2015, 113, 575-583.

4 Y. Sun, G. Sun, Y. Xu, L. Wang, X. Liang and D. Lin, Geoderma, 2013, 193, 149-155.

5 N. Bolan, A. Kunhikrishnan, R. Thangarajan, J. Kumpiene, J. Park, T. Makino, M. B. Kirkham and K. Scheckel, J. Hazard. Mater., 2014, 266, 141-166.

6 V. Sheoran, A. Sheoran and P. Poonia, Crit. Rev. Environ. Sci. Technol., 2010, 41, 168-214.

7 H. B. Cui, J. Zhou, Y. B. Si, J. D. Mao, Q. G. Zhao, G. D. Fang and J. N. Liang, J. Soils Sediments, 2014, 14, 1397-1406.

8 M. Vithanage, B. B. Dabrowska, A. B. Mukherjee, A. Sandhi and P. Bhattacharya, Environ. Chem. Lett., 2012, 10, 217-224.

9 X. Liang, Y. Xu, L. Wang, Y. Sun, D. Lin, Y. Sun, X. Qin and Q. Wan, Chemosphere, 2013, 90, 548-555.

10 A. Zanuzzi, A. Faz and J. Acosta, Environ. Earth Sci., 2013, 70, 2623-2632.

11 Z. Michálková, M. Komárek, H. Šillerová, L. Della Puppa, E. Joussein, F. Bordas, A. Vaněk, O. Vaněk and V. Ettler, J. Environ. Manage., 2014, 146, 226-234.

12 G. Garau, P. Castaldi, L. Santona, P. Deiana and P. Melis, Geoderma, 2007, 142, 47-57.

13 E. Madejón, P. Madejón, P. Burgos, A. P. de Mora and F. Cabrera, J. Hazard. Mater., 2009, 162, 931-938.

14 J. Fan, W. Ding and N. Ziadi, Commun. Soil Sci. Plant Anal., 2013, 44, 1224-1241.

15 H. R. Schulten and P. Leinweber, Biol. Fertil. Soils, 2000, 30, 399-432.

16 Q. Y. Wang, J. S. Liu, Y. Wang and H. W. Yu, J. Soils Sediments, 2015, 15, 1075-1082.

17 B. Huang, Z. Li, J. Huang, L. Guo, X. Nie, Y. Wang, Y. Zhang and G. Zeng, J. Hazard. Mater., 2014, 264, 176-183.

18 F. Madrid, M. Biasioli and F. Ajmone-Marsan, Arch. Environ. Contam. Toxicol., 2008, 55, 21-32.

19 J. Chen, F. He, X. Zhang, X. Sun, J. Zheng and J. Zheng, FEMS Microbiol. Ecol., 2014, 87, 164-181.

20 Z. Li, X. F. Chen and M. Liu, Sci. Agric. Sin., 2013, 46, 950960.

21 Y. Lu, S. Song, R. Wang, Z. Liu, J. Meng, A. J. Sweetman, A. Jenkins, R. C. Ferrier, H. Li and W. Luo, Environ. Int., 2015, 77, 5-15.

22 P. Li, X. X. Wang, T. L. Zhang, D. M. Zhou and Y. Q. He, J. Environ. Sci., 2008, 20, 449-455.

23 X. Y. Zhang, L. D. Chen, B. J. Fu, Q. Li, X. Qi and Y. Ma, Journal of Resources and Ecology, 2006, 26, 3198-3204.
24 E. Elliott, Soil Sci. Soc. Am. J., 1986, 50, 627-633.

25 P. L. Yang, Y. P. Luo and Y. C. Shi, Chin. Sci. Bull., 1993, 38, 1896-1899.

26 A. Walkley and I. A. Black, Soil Sci., 1934, 37, 29-38.

27 F. T. Bingham, Methods of Soil Analysis. Part 2. Chemical and Microbiological Properties, 1982, pp. 431-447.

28 M. Pansu and J. Gautheyrou, Handbook of Soil Analysis: Mineralogical, Organic and Inorganic Methods, Springer Science \& Business Media, 2007.

29 D. J. Walker, R. Clemente, A. Roig and M. P. Bernal, Environ. Pollut., 2003, 122, 303-312.

30 M. Jalali and N. H. Matin, Environ. Earth Sci., 2015, 73, 20472059.

31 V. Antoniadis, K. Damalidis and A. Dimirkou, J. Soils Sediments, 2012, 12, 396-401.

32 V. Antoniadis and E. Golia, Chemosphere, 2015, 138, 364-369.

33 M. Ashman, P. Hallett and P. Brookes, Soil Biol. Biochem., 2003, 35, 435-444.

34 S. DeGryze, J. Six, K. Paustian, S. J. Morris, E. A. Paul and R. Merckx, Global Change Biology, 2004, 10, 1120-1132.

35 A. Gunina, I. Ryzhova, M. Dorodnikov and Y. Kuzyakov, Plant Soil, 2015, 387, 265-275.

36 M. Tao, J. Zhou, J. Liang, H. Cui, L. Xu and Z. Zhu, J. AgroEnviron. Sci., 2014, 33, 1328-1334.

37 A. Fayiga and U. Saha, Soil Sediment Contam., 2016, 5, 7-23.

38 B. Seshadri, N. Bolan, H. Wijesekara, A. Kunhikrishnan, R. Thangarajan, F. Qi, R. Matheyarasu, C. Rocco, K. Mbene and R. Naidu, Geoderma, 2016, 270, 43-59.

39 P. Madejón, A. Pérez-de-Mora, P. Burgos, F. Cabrera, N. Lepp and E. Madejón, Geoderma, 2010, 159, 174-181.

40 M. J. Tao, J. Zhou, J. N. Liang, H. B. Cui, L. Xu and Z. Q. Zhu, J. Agro-Environ. Sci., 2014, 33, 1328-1334.

41 H. B. Cui, K. Q. Ma, Y. C. Fan, X. Peng, J. D. Mao, D. M. Zhou, Z. B. Zhang and J. Zhou, Environ. Sci. Pollut. Res., 2016, 10808-10818.

42 H. B. Cui, Y. C. Fan, L. Xu, J. Zhou, D. M. Zhou, J. D. Mao, G. D. Fang, L. Cang and Z. Q. Zhu, J. Soils Sediments, 2016, 16, 1498-1508.

43 A. P. Puga, L. C. A. Melo, C. A. de Abreu, A. R. Coscione and J. Paz-Ferreiro, Soil Tillage Res., 2016, 164, 25-33.

44 P. Bhattacharya, A. C. Samal, T. Bhattacharya and S. C. Santra, Int. J. Exp. Res. Rev., 2016, 6, 39-49.

45 P. J. Mrdakovic, S. Meland, B. Salbu and L. Skipperud, Environ. Sci.: Processes Impacts, 2014, 16, 1124-1134.

46 S. C. Wong, X. D. Li, G. Zhang, S. H. Qi and Y. S. Min, Environ. Pollut., 2002, 119, 33-44.

47 L. Xu, H. B. Cui, X. B. Zheng, Z. Q. Zhu, J. N. Liang and J. Zhou, RSC Adv., 2016, 6, 103955-103965.

48 G. Zeng, H. Wu, J. Liang, S. Guo, L. Huang, P. Xu, Y. Liu, Y. Yuan, X. He and Y. He, RSC Adv., 2015, 5, 34541-34548.

49 R. Xiao, M. Zhang, X. Yao, Z. Ma, F. Yu and J. Bai, J. Soils Sediments, 2016, 16, 1-10.

50 X. B. Zheng, J. B. Fan and J. Zhou, Agric. Sci. China, 2015, 48, 3201-3210.

51 J. Li, X. Y. Yang, B. H. Sun and S. L. Zhang, Journal of Plant Nutrition and Fertilizer, 2014, 20, 346-354. 
52 J. Six, C. Feller, K. Denef, S. M. Ogle, J. C. D. M. Sa and A. Albrecht, Agronomie, 2016, 22, 755-775.

53 P. Puget, C. Chenu and J. Balesdent, Eur. J. Soil Sci., 2001, 51, 595-605.

54 B. John, T. Yamashita, B. Ludwig and H. Flessa, Geoderma, 2005, 128, 63-79.

55 S. S. An, F. Darboux and M. Cheng, Geoderma, 2013, 210, 7585.

56 M. Hardie, B. Clothier, S. Bound, G. Oliver and D. Close, Plant Soil, 2014, 376, 347-361.

57 C. J. Bronick and R. Lal, Geoderma, 2005, 124, 3-22.

58 G. Xu, M. Liu and G. Li, J. Hazard. Mater., 2013, 260, 74-81.
59 R. Xiao, M. Zhang, X. Yao, Z. Ma, F. Yu and J. Bai, J. Soils Sediments, 2016, 16, 821-830.

60 L. Shen, A. Lo, X. Nguyen and N. Hankins, Sep. Purif. Technol., 2016, 159, 169-176.

61 H. Li, X. Han, F. Wang, Y. Qiao and B. Xing, Commun. Soil Sci. Plant Anal., 2007, 38, 1673-1690.

62 X. S. Wang, Y. Qin and Y. K. Chen, Environ. Geol., 2006, 50, 1061-1066.

63 R. A. Sutherland, Environ. Pollut., 2003, 121, 229-237.

64 M. Egli, G. Sartori, A. Mirabella, D. Giaccai, F. Favilli, D. Scherrer, R. Krebs and E. Delbos, Sci. Total Environ., 2010, 408, 931-946. 